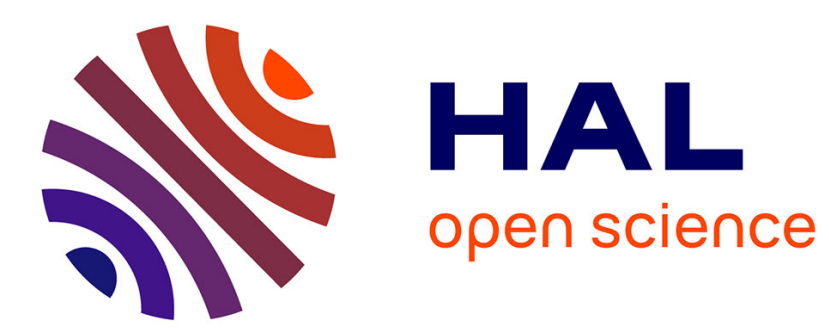

\title{
How Happiness can lead to more Efficiency? A New Paradigm Adapted to the World Knowledge Economy
}

Camille Baulant

\section{To cite this version:}

Camille Baulant. How Happiness can lead to more Efficiency? A New Paradigm Adapted to the World Knowledge Economy. The International Confederation of Associations for Pluralism in Economics Conference, Jan 2017, Chicago, United States. pp.15. hal-02528868

\section{HAL Id: hal-02528868 \\ https://univ-angers.hal.science/hal-02528868}

Submitted on 2 Apr 2020

HAL is a multi-disciplinary open access archive for the deposit and dissemination of scientific research documents, whether they are published or not. The documents may come from teaching and research institutions in France or abroad, or from public or private research centers.
L'archive ouverte pluridisciplinaire HAL, est destinée au dépôt et à la diffusion de documents scientifiques de niveau recherche, publiés ou non, émanant des établissements d'enseignement et de recherche français ou étrangers, des laboratoires publics ou privés. 


\title{
How Happiness can lead to more Efficiency? A New Paradigm Adapted to the World Knowledge Economy: \\ Camille BAULANT ${ }^{1}$ \\ December, $15^{\text {th }}$
}

\section{The International Confederation of Associations for Pluralism in Economics Conference, January 5, 2017, Roosevelt University, Chicago \\ Can Pluralism Save Economics? \\ Pluralistic Approaches to Teaching and Research in Economics}

Session 18: Power and Public Policy

\begin{abstract}
: 245 words
Over the last 20 years, the world economy has induced more competition and cooperation. To understand how cooperation is complementary to competition, the paper proposes to analyze both sides of the market economy: the competition side where agents compete with each other and the cooperation side where agents need to cooperate with each other. Despite a rising economic growth during the last thirty years, recent studies on happiness also show a gap between economic growth and life satisfaction (Eeasterlin, 1974, Helliwell, Layard and Sachs, 2016). This work seeks to study the conditions of a more inclusive economy allowing individuals and organizations to reach better efficiency and happiness. To realize this paradigmatic revolution, the paper suggests using the results of Shapiro and Stiglitz's efficiency wage theory for investigating necessary conditions for a more inclusive economy. In an inclusive growth, two aspects must be analyzed: the long run sustainable happiness and efficiency specialization for agents and countries and their short run daily happiness and efficiency. In the first part, the paper analyzes how recent world changes evolve to use a complexity theory (Le Moigne, 1995) which proposes qualitative inter-dependences between rationality and emotion for reaching rising efficiency. In the second part, the paper demonstrates how the individual strategies of the agents, led by the search for increasing happiness, may induce some long run innovations for the whole society. In the last part, the paper proposes concrete short run actions for greater individual and collective happiness and efficiency.
\end{abstract}

Keywords: Happiness, Collective Efficiency, Complexity Approach, Network Organization

JEL Classification Code: F40, L14, L16

\section{Word count: 6,139 words}

Over the last 30 years, the world economy has evolved at great speed and had induced two main changes. The first change concerns the rising paradox situation because countries have become more and more inter-dependants. On the one hand, globalization induces rising competition and on the other hand the Knowledge Economy must induce rising cooperation. The second change concerns a certain disconnection between the rise of economic growth and the rise in happiness or life satisfaction ${ }^{1}$. Despite a rising economic growth during the last thirty years, recent studies on happiness show in effect a rising gap between economic growth and the life satisfaction. In the Social Progress Index built by Porter (2016), the USA for example reached the $5^{\text {th }}$ world place world-wise range for its GDP/head in PPP $\$$ but only $32^{\text {th }}$ place for the well-being index. Since the Wealth of nations of Adam Smith (1796), the basic

\footnotetext{
${ }^{1}$ Professor in Economics at the University of Angers, GRANEM Laboratory, Faculty of Law, Economics and Management, 13 Allée F Mitterrand, 49000 Angers, France, Email : camille.baulant@univ-angers.fr. I thank Gemma Davies, Research Assistant at the Granem Laboratory of the University of Angers for helping me to improve the English of this paper.
} 
assumption made by economists is that economic progress involves happiness. However, some economists such as Shapiro and Stiglitz, following the first book of Smith on the Theory of moral sentiments ([1750] 1991) and Hume's conception ([1759] 1991), suggest, on the contrary that happiness may be a strong condition for efficiency. In order to understand how cooperation is complementary to competition and how state regulation is complementary to market regulation, the paper analyzes both sides of the market economy: the competition (where agents compete with each other) and the cooperation (where agents need to cooperate with each other). With the globalization of the economy, these two sides are today more important than before. The globalization of goods, capital and knowledge has induced rising competition and economic war (Aghion and al, 2005). On the other hand, the knowledge economy induces a collective innovation which necessitates more cooperation (Brown \& Duguid, 1991). The complexity approach developed by authors (Le Moigne, 1995) allows the analysis of the interactions between the two sides of the economy. Since the beginning of the economic science, the private market (the "invisible hand") seems to dominate the visible hand of each nation. The competitive markets reach cooperation situations through the price mechanism without agents knowing each other. The State-Nations institutions enable people to cooperate through several arrangements with the necessity of a voluntary cooperation. Since 1990, it has been necessary to investigate the inter-relations between these two kinds of institutions because of the evolution of the world division. Private companies thus need public interventions and public production (spatial conquest) needs private funds.

The starting point of this work is to analyze the conditions of a more inclusive economy in order to enable individuals and organizations to reach better efficiency and happiness. To realize a paradigmatic revolution, the paper suggests using the results of Shapiro and Stiglitz's efficiency wage theory. By putting human relations first, individuals will become more inventive and the sustainable economic growth may be reached. The common point of the efficiency wage theories and the inclusive growth is to reject equilibrium situations and linear economic development of countries (the Rostow's stages (1960) in economic growth). Defining inclusive growth is difficult because the authors fail to reach to a consensus. For some authors, inclusive growth is defined in an isolated sense and implies the reduction of inequalities for reducing the poverty across countries (Rauniyar and Kanbur, 2010). For the others, and it is the view defended in this paper, inclusive growth involves, in an enlarged sense, a global analysis of a sustainable growth capable of taking into account economic, social and environmental conditions (Stiglitz, Sen et Fitoussi, 2008). In both of the cases, inclusive growth is a dynamic development which is analyzed as a process (Klasen, 2010) and not as a result. Both of the following have to be studied in the inclusive growth process: how the long run trajectory of growth may involve a "Happiness Advantage" for individuals (Achor, 2010) and sustainable "Competitive Advantage" for organizations (Porter, 1990). In the long term analysis, the inclusive growth approach focuses on production views: how to increase production in order to respond to the demands of all consumers. For that reason, the use of the dynamic diamond allows relying supply to demand and cooperation to competition relationships. To define an inclusive growth for everyone in the long run, it is also fundamental to rethink the direct and indirect links between the microeconomics and macroeconomic determinants. The microeconomic dimension captures the strategies of each agent to reach better happiness and income through an innovation process in mobilizing his system 1 and system 2. The macro dimension refers to the institutional environment in terms of efficient organization and international openness in goods, capital, and knowledge mobility and dynamic cooperation and competition processes. As there is no linear evolution, the time process of inclusive growth also needs to be studied in the short run in order to investigate the concrete actions of individuals and organizations. The use of Emotional Intelligence induces greater happiness for individuals (Goleman, 2011). The use Competitive Intelligence induces more efficiency for the organizations (Jakobiak, 2004).

In the first part, the paper analyzes how recent world changes evolve to use a complexity theory which proposes qualitative inter-dependences between rationality and emotion for 
reaching rising economic and social efficiency. In the second part, the paper demonstrates how the individual strategies of the agents, led by the research of increasing happiness may induce some long run innovations for the whole society. In the last part, the paper proposes concrete short run actions for greater individual and collective well-being and efficiency.

\section{THE COMPLEXITY APPROACHES LINK ECONOMIC WEALTH AND HAPPINESS}

Over the last 30 years, the free movements of goods, capital assets and knowledge among countries had induced rising competition and the new place of emerging countries in the world economy (Aghion and al, 2005, D'Aveni, 2012, Helpman and Krugman, 1985). On the other side, the complexity of the new International "Division of Cognitive Labor" (D.C.L.) involving a knowledge specialization necessitates more cooperation within each organization (Brown \& Duguid, 1991, Nelson and Winter, 1982). In this process, agents need to cooperate with others to co-build new knowledge. Despite the rising economic growth of all countries for the last 30 years, happiness does not follow the economic growth (Clark, Flèche, and Senik, 2016, Eeasterlin, 1974, Inglehart, \& Baker, 2000). For example, the USA for example reaches the $5^{\text {th }}$ world place for its GDP/head in PPP $\$$ but only the $32^{\text {th }}$ place for the in the Social Progress Index built by Porter (2016). The Attali Working Group on the "positive economy" remarks for example, that France is ranked $5^{\text {th }}$ for her economic activity but only $22^{\text {nd }}$ for her social and environment activity (Attali, 2013).

In order to decrease the gap between wealth and happiness, some economists recommend using "economic war" tools in order to increase their economic power on the world market (Baumard, 2012; Harbulot, 2014). On the contrary, other economists propose a rising human development where everybody could live together in happiness (Attali, 2013, Delmas-Marty, 2016, Morin, 2011, Sen, 1999). However, these two binary answers have to be analyzed into a complexity approach which is the only one which allows thinking and acting in a complex world. Using the complexity approach enables the linking of opposite factors: individuals and organizations, local and global dynamics, long run and short run horizons, top down approach or bottom up approach, rational or emotional behaviors (Kahneman, 2011, Goleman, 2014). The complexity approach links opposite factors into qualitative inter-dependences of order (organization) and complexity (innovation). Through this dynamic process, the complexity sciences analyze these interdependences across several time periods (long run, short run) and several areas are considered (local, global). The complexity approaches can be formalized by a dynamic "diamond" (Le Moigne, 1995) or a dynamic "wind rose" (Delmas-Marty, 2016). Both of them interlink two opposite behaviors (security versus freedom, competition versus cooperation) in order to innovate and reach better economic and social efficiency (Figure 1).

The links of these two opposite factors are today important to reach happiness and efficiency in a knowledge economy. With the Division of Cognitive Labor (DCL), individuals have to learn to use more and more cooperation relations for innovating together (Muldoon, 2013). With the uncertainly of the global economy, individuals have to develop both reason and emotion behaviors (Goleman, 2014, Kahneman, 2011). 
Figure 1: Complexity Approaches and "emerging proprieties"

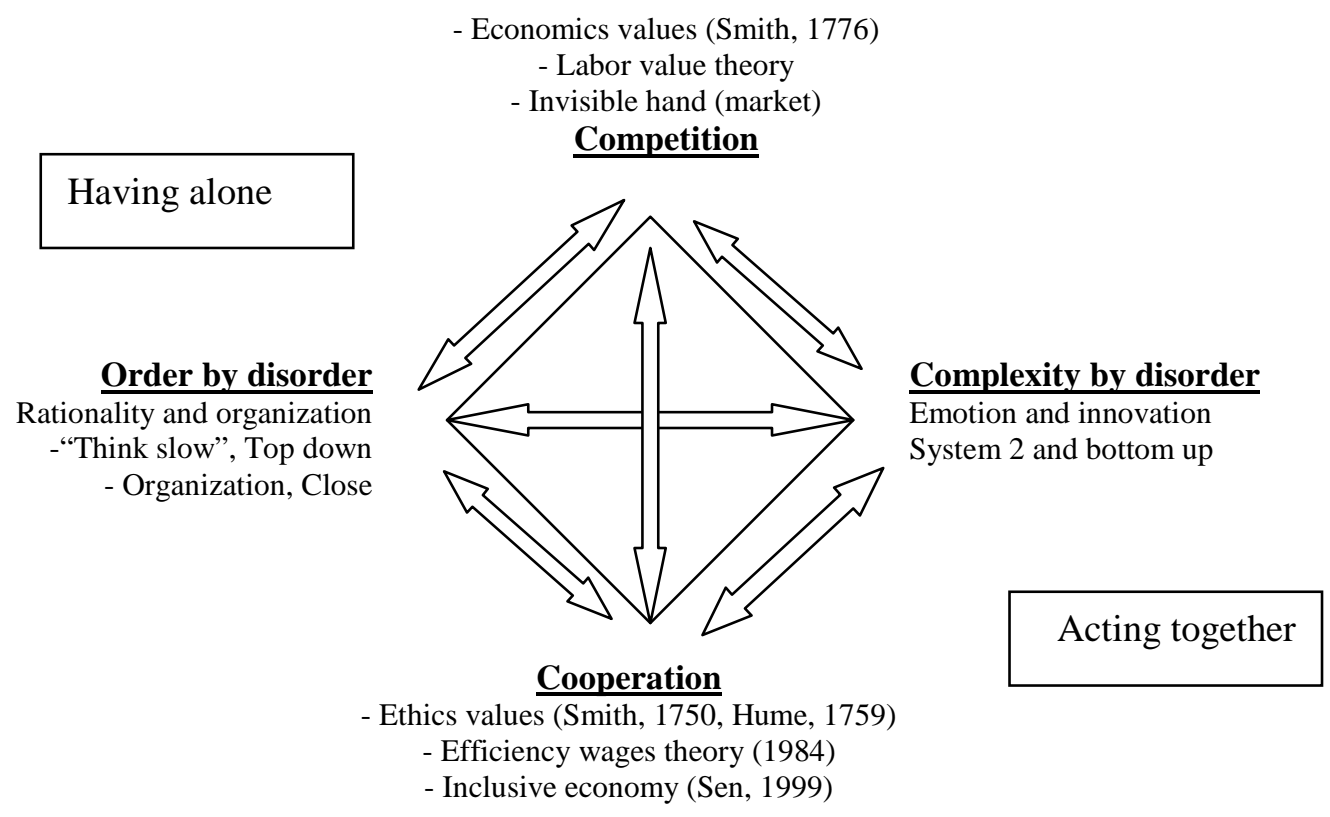

Source : Atlan, 1979, Koestler, 1988, Morin, 1981, Le Moigne, 1995

\section{$\underline{1 . \text { Linking competition and cooperation strengths }}$}

Since 2000, the world Cognitive Labor Division (C. L. D.) involves that individuals and organizations have to learn to use more cooperation relations for innovating together (Muldoon, 2013). This new approach of the cooperation is opposite to the preceding period (1980-2000) where global firms practice non price specialization (Krugman and Helpman, 1985) in choosing each country to efficiency realize one part of the output process (research, producing, selling) and thus make the countries in competition (the world Manufacturing Labor Division -M.L.D.-).

Since the beginning of political economy, we meet competition and cooperation relationships. The classical economic theory (Smith, 1776) separates economic relationships founded on the "labor value theory" from the social relationships based on the "fair price' of Santa Thomas Aquinas and from the political relationships, developed by the Mercantilism theory. However, Smith, in his first book on the "theory of moral sentiments" ([1750] 1991) and others classical economists such as Hume ([1759] 1991) or Mills ([1833] 1981) analyze the interrelations which exist between these three types of fields: economic, social and politics. The global approaches of Economics were developed by the institutional approaches (Veblen, 1895; Polanyi, 1944) which insists on the role of the institutions to stabilize the economic and social relationships. During the Post-Second World War period (1945-1975), the global approach mixing economic, social and politics were analyzed by the post-Keynesian economists, and particularly the French School of Regulation (Aglietta, 1976; Boyer and Mistral, 1978) who highlight the role of three national institutions (employment relationships, money, and public welfare) to involve a virtuous circle between the economic growth and the standard of living in advanced countries. Today, the approach of inclusive economy involves a global approach linking economic, social and politic. Defining inclusive growth is difficult because all the authors fail to reach to a consensus. For some authors, inclusive growth must be defined in small sense and implies to reduce inequalities for reducing the poor among the country (Rauniyar and Kanbur, 2010). For the others, and it is the view defended in this paper, inclusive growth is defined in a large sense and involves a global analysis of a sustainable growth able to take into account economic, social and environmental conditions (Stiglitz, Sen et Fitoussi, 2008). In the two cases, inclusive growth is a dynamic development which is analyzed as a process (Klasen, 2010) and non as a result. 
The complexity approaches, developed by Edgar Morin (1981), and Arthur Koestler (1988), show the role of feedbacks between organizations and markets. The dynamic feedback between individuals are able to co-create an intermediary level (network, communities of practice) in order to stabilize the behaviors of the individuals in producing "regularities by disorder" and in producing "complexity by disorder" (Atlan, 1979). With the knowledge economy during the nineties, we observe a renewal of the complexity theory with Le Moigne (1995) and Foray and Bengt-Ake (1996). Economists as Daniel Cohen (2013) and Jacques Attali (2013) consider it increasingly necessary to study the conditions of the individuals' happiness to propose a new economic regime, more founded on human relationships. The complexity approach formalizes the interactions which exist between individuals, organizations, and environment which are co-built by a combination of all of them. In an economy which tends to become inclusive, it is important to analyze the contradictory relationships which exist between the degree of liberty of each individual and the degree of cohesion of the whole society. In this analysis, the agents have to stay open to the external environment in order to innovate and have to be constraint by the internal organization through the technical and social path dependency.

The key element in the complexity approach is therefore to dynamically connect the competition and the cooperation relationships. On the one hand, the cooperation relationships involve some increasing external scale economies for all the agents. On the other hand, the authority relationships give a stable direction that agents could follow over a certain period of time. The disorder process and the authority process co-evolve to exploit the innovations which emerge from these frequent interactions. In the hard sciences such as Mathematics, Edgar Morin, 1981 already shows that the "negative feedbacks" (orders created by disorder) are more important than the "positive feedbacks". Contrary to the soft sciences, as in the social sciences, the positive feedbacks (involving complexity) are more important that negative feedbacks (involving stability). Jean-Louis Le Moigne (1995) analyzes the specific case of the engineering sciences which are in between the hard sciences and the soft sciences. This intermediary position is interesting because this level has specific proprieties. Leonardo da Vinci noted, referring to the painting Mona Lisa, how he wanted to paint " $a$ budding smile". Along the same lines, Paul Valery (1989) evoked the specificity of the "water's surface" which is neither water, nor air but in between. These intermediary levels are used to mix opposite factors such as ethics and sciences, emotion and rationality, dream and reality (Piaget, 1976). In this organizational process, order is related to complexity by the concept of "emergence proprieties" (Atlan, 1979). In emergence proprieties, the relationships between individuals are more important than the individuals alone and the interactions finally create organizational levels which could become independent from the individuals. The emergences proprieties may thus stabilize the behaviors of the individuals and the whole over a certain period of time by creating such intermediary levels. This level plays the role of a "meta level" edicting general rules able to stabilize the agents' behaviors (Watzlawick, Beavin and Jackson, 1972) or "meso levels" allowing more flexibility within the global system (Atlan, 1979). Meta and meso levels therefore escape from a binary approach which opposes the individualist approach to the holistic approach.

\section{Linking system 2 and system 1}

In a knowledge economy, individuals and organizations may be happier and more efficient if they accept and use the two parts of their brain: emotion and reason in order to increase their collaboration relationships that are today necessary for increasing qualitative innovations and happiness for each person within all societies. In order to further study the analysis of the actual knowledge economy, it seems interesting to analyze the approaches developed by the authors of the positive psychology (James, 1890, Langer, 1989, Goleman, 2014). All these positive psychologists propose a dynamic way for thinking using reason and emotion. The positive feelings seem powerful engines which increase happiness and efficiency for all individuals. Leaving the systemic approaches, which just give the same weight to all opposite 
factors, positive psychology proposes to reverse the relationship between rationality and emotion. Positive feelings make the people more innovative and pro-active in the knowledge economy. "Your life therefore goes well when you feel happy" (Dolan, 2014: 5). In the knowledge economy, being rational -supposing that agents know how to define rationality ${ }^{2}$ is not sufficient. The use of emotion in the decision making is analyzed by all behavioral economists. Daniel Kahneman (2011) determines how agents must think both "slow" ("system 2", with their rationality) and "fast" ("system 1", with their emotion).

Psychologists working on well-being and happiness (as Langer, 1989, Seligman, 1998) point out two main characteristics to obtain better economic and social results for individuals and society. First, in developing a positive spirit, individuals are able to work longer, harder, and quicker. Second, individuals dropt their "perfectionist behavior" -work hard to be happy later- and adapt an "optimalist behavior" -be happy today to have better results tomorrow(Ben Shahar, 2007: 18).

The use of emotions in the decision making process is also analyzed by researchers in business and management. Collins (2001) and Goffe and Jones (2011) point out the key role of "emotional intelligence" (Goleman, 2011) to analyze the key role of the leadership in the knowledge economy. In the knowledge economy, controlling every thing and avoiding "free rider" behaviors becomes impossible. In this situation, controls may be replaced by "prechoices" and "pro-action" behaviors for all of the actors. The pre-choice developed by Kahneman (2011) and the "nudges" analyzed by Thaler and Sunstein (2007) may be used by all the policy makers for helping people make good decisions. For Garvin and Roberto (2013) for instance, the decision making is becoming a process where leaders in private organizations have to be sure that everybody in the organization will have a real interest to apply the global firm's strategies. And in doing in such, the leader does not have to control all the employees working within the company. This new kind of leadership leaves each employee autonomous and gives good incentives without constraining employees. In private companies as well in the national economy, the Competitive Intelligence Approaches (Baumard and Harbulot, 1999, Massé and Thibault, 2000) are looking to formalize the complete information cycle process in such a way that individuals and private companies would be able to adjust to the complexity of the world knowledge economy and to pro-act in this moving world. The competitive Intelligence approach is therefore a new way of thinking about the complexity of the world and the new way to act (with pro-action behaviors) in this evolving world (Levet, 2001).

\section{HOW DESIGNING LONG RUN HAPPINESS AND COMPETITIVE ADVANTAGES?}

In the world knowledge economy, which involves an inclusive growth process, it is important to analyze: a long run trajectory of specialization able to involve a "Happiness Advantage for individuals" studied by Achor (2010) and the "competitive advantage for organizations" analyzed by Porter (1990). In this long term analysis, the inclusive growth focuses on production views: how increasing production in responding to the demand of all the consumers. For that reason, the use of dynamic diamonds allows relying supply to demand and cooperation to competition relationships. To define an inclusive growth for everybody in long run, it is important to rethink the direct and indirect linkages between the microeconomics and macro-economic determinants. The microeconomic dimension captures the strategies of each agent to reach better happiness and income through innovation process and in mobilizing system 1 and system 2 to do it. The macro dimension refers to the institutional environment in terms of internal organization, international openness, cooperation, and competition.

\section{Long run "Happiness Advantage" for individuals}

In a knowledge economy, the question is how the individuals mobilize different factors in order to increase happiness through inducing efficient cooperation among individuals, as it is impossible to "order" individuals to cooperate with one another. Understanding the 
interrelations between opposing feelings such as being closed and being open are important for encouraging people to form cooperation relationships. In building the "happiness advantage", Achor (2010) and other psychologists (Langer, 1989, Ben Sahar, 2010, Seligman, 2011, Goleman, 2011) use the concepts carried over from the complexity approach. The feedback effects are important to create the "emergence proprieties" described by Atlan (1979).

In the "happiness diamond" (Figure 2), four factors allows to individuals to increase their long run happiness: positive feelings, being open, trust others and self-trust.

Figure 2: Long run Happiness Advantage Diamond for Individuals

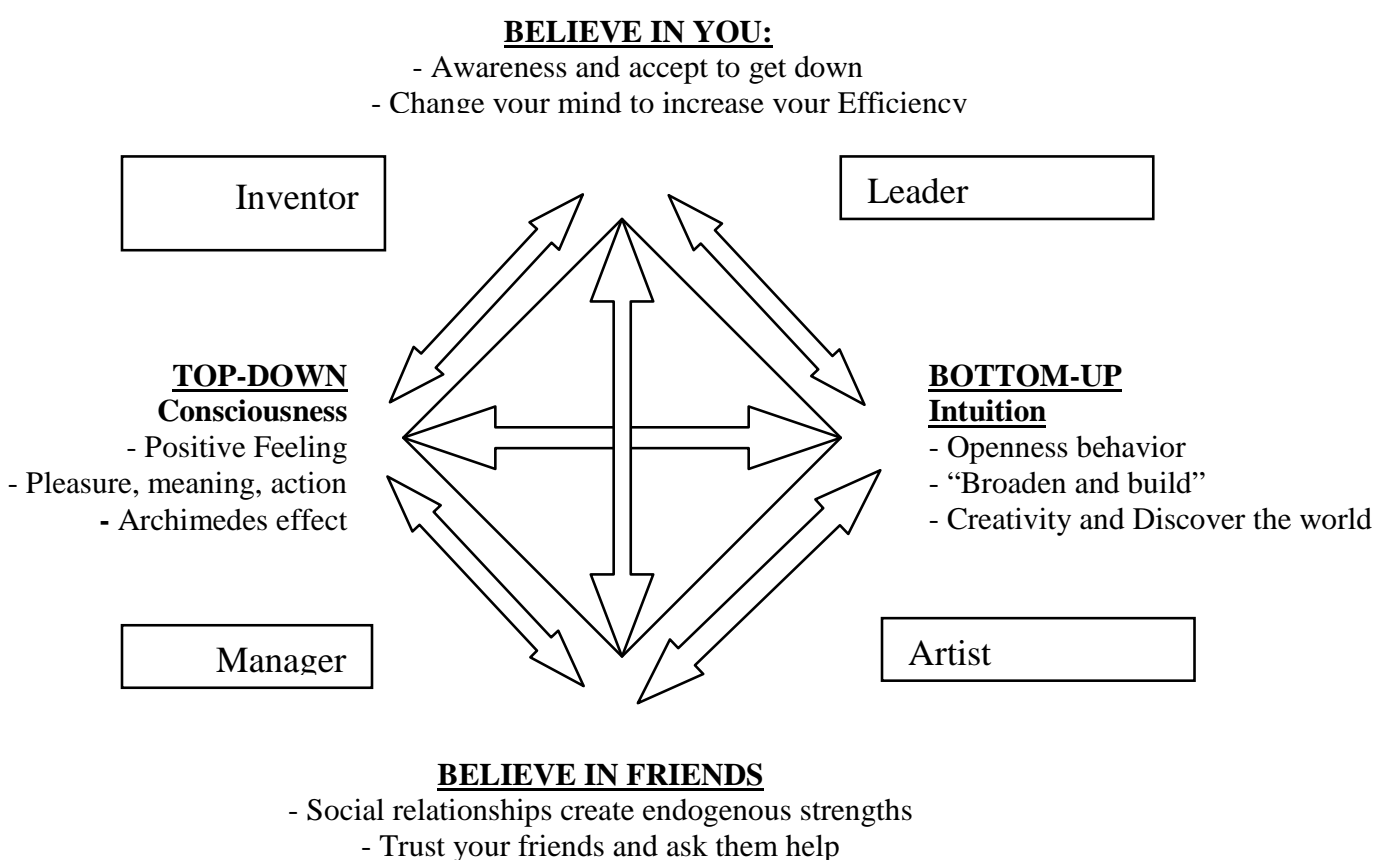

Source :W. James, 1892, Langer, 1989, Goleman, 2011, Ben-Sahar, 2007, Achor, 2010

For the development of positive feeling, each agent has to be able to change his mind and learn to think positively. For example thinking about their actions in the long run (projects, inventions, way of life...), having positive feelings induces the three components of happiness": "pleasure", "meaning" and "engagement" analyzing Martin Seligman (2011) in his concept of "full feeling close to Aristotle's concept of "Eudaimonia". For Paul Dolan, "happiness is experiences of pleasure and purpose over time" (Dolan, 2014: 3). This definition of happiness induces a two by two model which mixes feelings (positive or negative) and purpose (with or without motivation). This analysis helps us to understand the power of positive feelings (such as joy or excitement) and the power of the motivation (that can also be associated with negative feelings such as anxiety or anger). The feedback between feelings and motivation has the power to transform our weaknesses into strengths and threats into opportunities. The knowledge economy process involves the emergence of a new paradigm concerning the scientific process: it is happiness which creates success ${ }^{3}$. A lot of experiments carried out in psychology show that "thinking positively" makes us more intelligent, more motivated and more powerful (Kahneman, 2011, Langer, 1979). The second factor of the happiness diamond is to "think out of the box". In being "open" to innovations, individuals can avoid what Shawn Achor calls the "Tetris effect". The Tetris effect is like an addictive video game which creates repeat cognitive pictures in our brain. People, who are video game addicts, are therefore not capable of thinking differently from usual. The third required factor to reach happiness is that individuals have to be able to think for themselves. In order to innovate, each person has to believe in his own influence. It is the famous "lever effect" described by Archimedes: "Give me a place to stand and with a lever I will move the 
whole world" . In everyday life, the "place to stand" could be represented by our capacity and our knowledge to improve each day. The "lever" could be represented by the mindset that we have when we want to change the world. Changing our mind and deciding to have positive thoughts and feelings could induce the success of our actions ${ }^{5}$. The last factor of the happiness process is to develop confidence in others: Shawn Achor describes in his book a fireman's exercise he carried out when he was young and where confidence in others was crucial. Every time, we face difficult situations, the panic feeling is the worse solution because it overwhelms us and we forget to trust others. For most psychologists (Kahneman, 2011, Langer, 1979, Seligman, 1998), social relationships represent a powerful investment required in order to build a real competitive advantage. When you are supported, it is easier to manage adversity and transform it into opportunity for personal development. All together, these four psychological factors: positive feelings, openness, self-confidence, and confidence in others interlink and connect individuals to the others by creating sustainable happiness advantages for all.

\section{Long run Competitive Advantage for organizations}

In a knowledge economy, the individuals who seek happiness also have a better efficiency when they work within productive networks. The creations of collective networks within organizations allow the building of sustainable competitive advantages for organizations and countries (Figure 3).

\section{Figure 3: Long Run Competitive Advantage for Organizations}

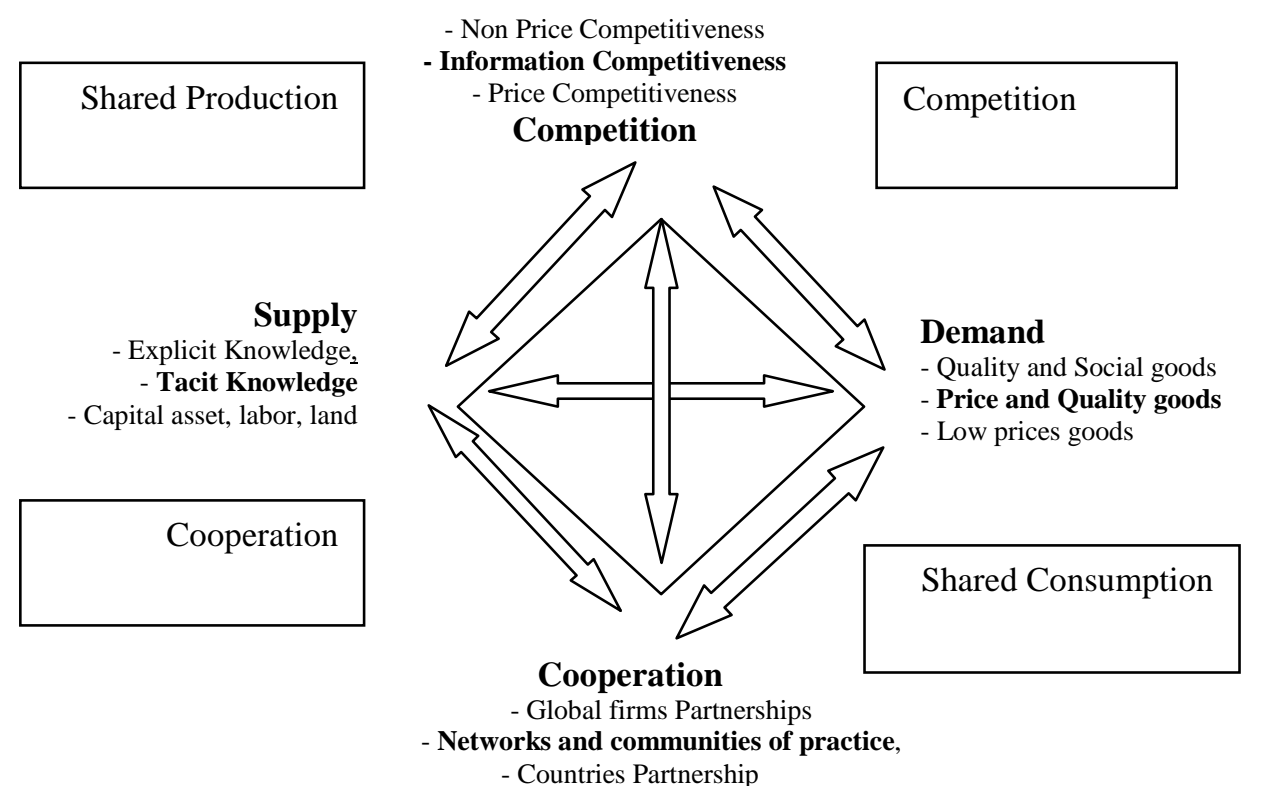

Source: Porter (1990), Baulant (2015)

The results of psychologists' research concerning happiness (Goleman, 2014, Langer, 1979) may be used to reach sustainable competitive advantages created by Porter in 1990. The building of happiness advantages seems thus important for the motivation of the agents for building cooperation networks. In this analysis, the social factor (happiness advantage) induces the economic factors (competitive advantage). It is therefore possible to build new relations between supply and demand factors, and between cooperation and competition behaviors, capable of inducing a rising social and economic efficiency. The rising efficiency is obtained by combining cooperation and competition relationships to innovate on the whole share value chain (Drucker, 2011, Foray and Lundvall, 1996, Porter, 1990, Kotter, 2011). Cooperation and competition networks may generate rising internal scale economies for each agent and rising external scale economies for the society as a whole. In the sustainable 
competitive advantages, all the agents reach win-win situations by building networks in proposing their own specific supply factors (labor or capital but also explicit and tacit knowledge..) in accord to the specific demand they want reach (high quality goods, better quality-price goods, low price goods). Finally, they reach different kinds of innovations: radical innovations, market innovations or frugal innovations ${ }^{6}$. Porter's analysis, considers that it is more important to be able to make an innovation that is well adapted to the consumers' needs, on the market.

\section{HOW ACTING IN THE SHORT RUN BY USING EMOTIONAL AND COMPETITIVE INTELLIGENCE?}

As there is no linear evolution toward the long run sustainable advantages, the time process of a knowledge economy has to be studied in short run to think the action of individuals and organizations. Each agent has thus to build in short run his strategy in pro-acting into his environment. In the short run the comparisons to others dominate (Simon, 1955, Watzlawick, Beavin and Jackson, 1972). Strategic relationships remain therefore determinant in the short run. Organizations constantly have to face constraints of time, space, technological dependency. They also face the constraints of their competitors who have already innovated on the same type of product. The new kind of short run strategies, induced by the knowledge economy, involves a more network organization mixing happiness of individuals and efficiency of organizations. In a moving and uncertain world, one of the most difficult things for individuals and organizations is to begin acting, "to put their shoes on", as William James, the famous psychologist of Harvard used to say.

\section{Using Emotional intelligence to be happier}

For all the individuals, using emotional intelligence induces greater happiness, as analyzed by Goleman, 2011. To reach a greater efficiency in an individuals' action, the problem is that each individual must know how to begin their action. The researches of psychologists (BenSahar, 2007, Langer, 1989) show that it is impossible for people to be courageous and efficient all their life. Therefore, habits and routines seem much more powerful than motivation, when spurring action. The action triangle, proposed in Figure 4, summarizes the three main actions that individuals should undertake in order to begin to act positively.

Figure 4: The Emotional Intelligence leads individuals happier

Accept and recover from failure:

- Change your mental map: stronger after the failure

- Intermediary objectives and a small amount of power.

Create new goods habits:

- Transform your work in creative labor

- Create habits in 21 days

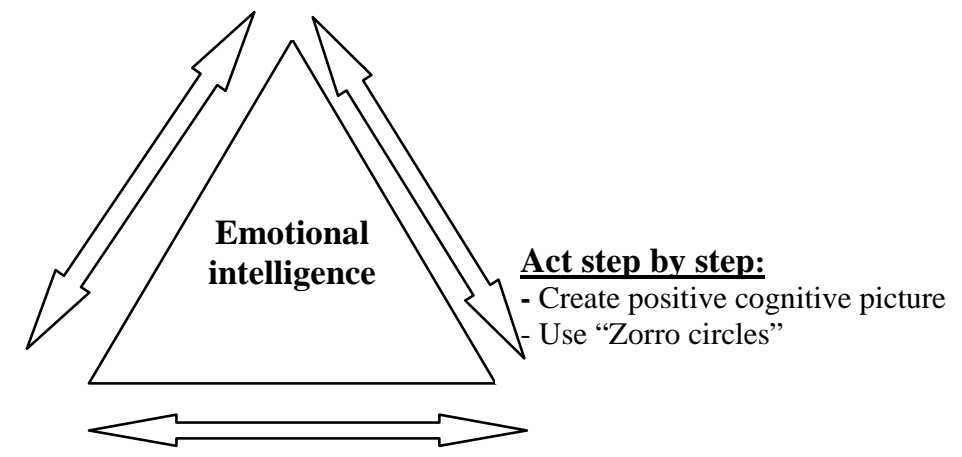

Source: James, 1892, Goleman, 2011, Achor, 2012, Dolan, 2014

The first factor is to create new habits. William James (1890) analyzes all the actions that people carry out every day: brush their teeth; put the alarm clock on ... These actions do not require effort as they form part of a daily routine. Shawn Achor (2010) and Paul Dolan (2014) enlarge this analysis to other topics which also induce collective consequences. For example, most people agree to never drive when they feel that they have drunk too much alcohol. However it is difficult to know if people are able to drive after one or two glasses. Therefore, 
the authors suggest that one should decide not to drive when one has drunk any alcohol. With this type of action, people don't have to ask themselves the question: "Am I OK to drive?" This "pre-choice" is very useful as it helps individuals become more efficient as they don't have to ask themselves the question each time they drink alcohol. They can also choose the lazy option which is easier to carry out. Following a similar approach, Richard Thaler and Cass Sunstein (2007) and Daniel Kahneman (2011) show the role of the "nudge" used to make these kinds of pre-choices. "Nudges" are specific habits which help people make the right decision, as for example encouraging people to engage in a sport to avoid stress and health problems. The analysis of a nudge is interesting because it can be applied at all levels of decision making (individuals, networks, State). The idea of a nudge for decision making could be applied for establishing new public policy at a macro level. For example, changing the law concerning organ donation, where consent is presumed unless an individual has registered a prior refusal, as in Wales, UK from $1^{\text {st }}$ December 2015. This new law could enable more lives to be saved without any constraint or action from individuals. The second factor for spurring action is to "walk one step at a time". Shawn Achor makes reference to the famous hero of Zorro in his book "How to become a contagious optimist". He uses the example of Zorro to demonstrate the transformation from someone who is afraid and lacking self-confidence to the story's hero. Before leaving one's comfort circle, people need to learn to control emotion, to know their capabilities, to trust that their capabilities will enable them to reach their objectives. This kind of analysis is very close to the analysis of Emotional Intelligence developed by Daniel Goleman in 2014. In the two analyses, individuals have to concentrate their efforts on limited objectives that they know they are able to attain. Shawn Achor uses an interesting example of an ill old woman, living in a retirement home, who increases her health and her moral by taking care of a house plant. Tal Ben-Sahar (2007) also suggests that people need to switch from a "perfectionist behavior" to an "optimalist behavior". The third and last factor required, in order to efficiently act, is to know how to take risks and how to be able to accept failure. Individuals could accept failure in two cases. First, by considering that they failed because of the external competition and that they thus compare their action with those of other people. Second, the individuals consider that they are to face an internal competition and they, in this case, compare their present performance to the expected performances they thought able to reach. Psychologists remind us that most famous people succeed because they failed in the past: for example Edison who tried several times before succeeding (Collins, 2011). If we accept failure and are willing to try again, we will enter into a dynamic process which transforms weaknesses into strengths and threats into opportunities.

\section{2) Using Competitive Intelligence to be more efficient together:}

Within organizations, acting in short run involves to practice competitiveness. With time, the competitiveness switches from the price and quality competitiveness to information competitiveness which is based on the Competitive Intelligence approach (Baulant, 2015). In competitive intelligence, which develops since 1990, building networks is important to innovate and sell in a global economy. In a knowledge economy, everybody may produce efficient innovations because of the role rising role of frugal innovations. It is thus important to pro-act in the short run in the world market and not only to adapt their goods to world market. The competitive intelligence involves the management of the whole information cycle. Hence, the Competitive Intelligence approaches (Ansoff, 1975, Wilinski, 1967), beginning during the sixties ${ }^{7}$, have come about a second time during the nineties because information and knowledge are now determinant for new production and the consumption processes. Because information and knowledge are public goods, all the actors within organizations have to cooperate by using networks to benefit from the rising external scale economies. The aim of the Competitive Intelligence methodologies (Baumard and Harbulot 1997, Bloch, 1999, Jakobiak, 2004) is to increase the information competitiveness of agents by transforming information into knowledge and then, by transforming new knowledge into useful information. The management of this information cycle allows organizations and 
countries to act quicker and with greater depth on the world markets. By using competitive intelligence acting on the world markets, the organizations build different kinds of networks (Figure 5).

\section{Figure 5: The Competitive Intelligence leads organizations more efficient}

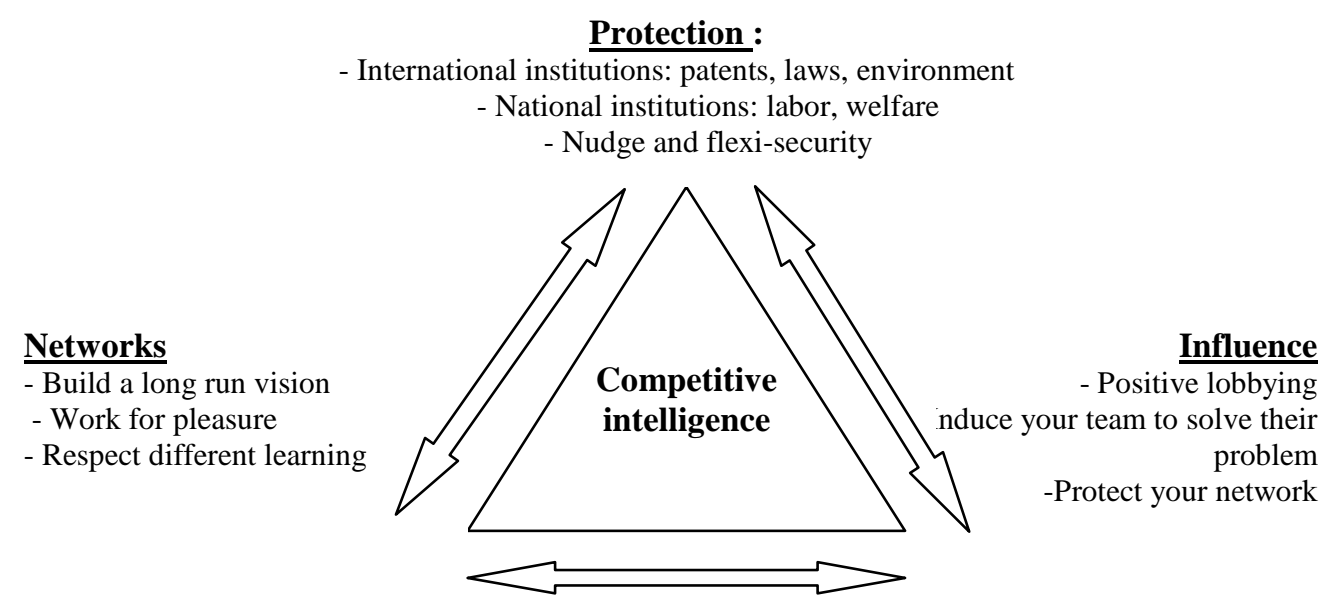

Source : Wilinski, 1967, Baumard and Harbulot 1997, Levet, 2001, Baulant, 2015

In order to sell goods on world markets, the first step for organizations is to build different networks founded on cooperation process. These networks are today crucial to induce useful learning processes between all agents within a community of practice or a private company. With the I.C.T. Revolution, Internet networks become more important for co-acting in a knowledge economy (as the social networks for example). The second step is to develop positive lobbying. With Internet, positive influence may be as powerful as negative influence. In positive lobbying, agents pro-act fair information which allows a rising preservation of the planet and a rising well-being for people around the world. In negative lobbying, agents proact information which allows them to have increased power in economic, political, social spheres. The third step in the competitive intelligence acting is to build institutional networks capable of protecting long run innovations and internal organizations within the world economy. Institutional networks help to establish new kinds of action that aims to increase the economic and social efficiency of all agents. For example, they help agents find financing for their individual invention, in using the crowd-funding systems on social networks. The institutional networks may also be useful for small private companies to protect their immaterial knowledge, by helping them to write patents in international institutions. Finally, institutional networks may help consumers or producers associations by using the international laws to defend their rights. All these institutional networks (regional organizations, Non Governmental organizations ...) help individuals, companies, and countries to efficiency act and protect their knowledge.

\section{Conclusion}

Globalization and the knowledge economy lead to an increasingly complex world. In such a world, the first result of the study shows the importance of the complexity approaches which link opposite factors (reason and emotion) and different research fields (economics and psychology). The pluralistic approaches allow individuals to improve their reasoning and their action in a knowledge economy. The analyses of the interrelations between contradictory factors allow the preservation of the diversity of all points of view. More precisely, understanding the interrelations between cooperative and conflict relationships induces the building of organizational networks that are capable of being flexible enough to invent new solutions and fixed enough to stabilize the behaviors of agents in an uncertain world.

The second result shows how the willingness of each agent is important, for the cooperation with others for acting in an inclusive economy and reconciling economic and social 
efficiency. On this point, the time horizon plays a determinant role into the cooperation process. In the long run, individuals and organizations have to think by themselves for creating innovations founded on their own diversity (feelings, way of thinking, confidence in themselves and others). Results of researches in positive psychology concerning the sustainable "happiness advantage" philosophy may be extremely useful for the economists for designing sustainable "competitive advantages" for organizations. Dynamic feedbacks between supply and demand and competition and cooperation factors induce rising economic and social efficiencies that generate more happiness for individuals and more innovations for the organizations. By inter-linking opposite factors, the study shows that everyone can invent his own sustainable competitive advantage. However, even if these long run strategies induce higher efficiencies, the individuals live in a tangible reality, where things can sometimes go quickly and sometime slowly. In the short run, each individual has to become pro-active and not only adaptive or anticipative. The acting process is founded on the confrontation of the agents with others. Agents have to act with the reality of competition and dependencies. Acting together is difficult because the "invisible hand" of the market often fails to reach higher efficiency. It is therefore crucial to study how each individual may increase life satisfaction. In the short run, individuals have to adopt new good habits, work step by step, and ask for help from others. Each individual may become happier if he considers his diversity as a strength rather than a weakness. Individuals who succeed are often those who have accepted failure in the past and have sought help from others (Abraham Lincoln, Thomas Edison, Michael Jordan...). Following the Emotional Intelligence process defined by Goleman (2011), when people put human feelings in the center of strategies, the short run acting becomes more efficient. The study argues that the people who manage their individual life with happiness will also be able to manage their collective acting in a world economy more efficiently. In the knowledge economy, people have to be more autonomous and also more linked to others. With the ICT revolution, the Competitive Intelligence process allows the transformation of raw information into useful information for acting with efficiency. Firstly, building this virtuous information cycle by using networks stimulates different kinds of learning. Secondly, agents also have to practice positive influence within and outside their networks when they want to diffuse their knowledge and products around the world. Thirdly, agents have to trust the institutions which protect their innovation in order to pursue their ideas and obtain rising efficiencies.

The last result of this study concerns the link that exists between individual happiness and the collective efficiency which may be used to solve a lot of tangible economic and social problems: environment problems, rising inequalities, and unhappiness. In each case, working together involves happiness and efficiency for individuals, organizations, and countries. For all of these agents, thinking differently and sharing with others allows the building of organizational networks where the whole is more than just the sum of the parts. The famous Newton's sentence in the XVIII ${ }^{\mathrm{e}}$ century remains therefore cutting edge: we are "dwarfs mounted on the shoulders of giants".

\section{Notes}

(1) Most of the authors prefer to talk about "life satisfaction" rather than "subjective well-being" or "happiness". Subjective well-being is different from one individual to another individual and it is difficult to define happiness out the philosophical field. A famous paper of Kahneman and Deaton (2010) demonstrates that the increase of GDP per head induces an increase of life satisfaction and not necessary in subjective well being.

(2) The rationality studies are more complex than they seem. Simons (1955) distinguishes the "procedural rationality" from the "bounded rationality". The last one seems to be well adapted to the situation of radical uncertainly. The agents just adopt the first best solution they meet.

(3) The knowledge economy and the ICT Revolution involve a "new paradigm", in the sense of Thomas E. Kühn (1989), which could be compared today to the "Copernicus Revolution" (1542), where Copernicus discovered that the earth goes round the sun.

(4) Archimedes: "Give me a place to stand and with a lever I will move the whole world" in Chiliades 2, p 129-130 (translated by Francis R. Walton). 
(5) For the same reason, it is so difficult to change bad habits because people do them without effort and without of thinking of the consequence (free rider behaviors for example). Most psychologists (William, Schwartz, Gardner, Langer, Seligman, Gilbert, Goleman) recommend that we should create new small habits. The authors of the behaviorist approach of economy (Kahneman, Dolan, Thaler, and Sunstein) and the authors in management and business administration (Porter, Drucker, Davenport, Kotter, Ancona, and Garvin, Roberto) also take into account the important role of habits for making good decisions.

(6) The competitive advantage approach is far removed from the "non price advantage theory" of Helpman and Krugman (1985), where the success of the firm depends on its size.

(7) Even if Competitive Intelligence processes are not new (Wilensky 1967, Ansoff, 1975), the Competitive Intelligence practices sharply increased from 1990, with the end of the "cold war".

\section{Bibliography}

Achor, Shawn. The Happiness Advantage. New-York, USA: Crow Business, 2010.

Aghion, Philippe, Nick Bloom, Richard Blundell, Rachel Griffith \& Peter Howitt. "Competition and Innovations: An Inverted-U Relationship.” Quarterly Journal of Economics 120, 2 (2005): 701-728.

Aglietta, Michel. Régulation et crise du capitalisme : l'expérience de Etats-Unis. Paris, France: CalmanLevy, collection perspective de l'économie, 1976.

Ansoff, H. Igor. "Managing strategic surprise by response to weak signal." California Management Review 18, 2 (1975): 21-33.

Atlan, Henri. Entre le cristal et la fumée: Essai sur l'organisation du vivant. Paris, France: Seuil, 1979.

Attali, Jacques (groupe de réflexion présidé par). Pour une économie positive. Paris, France: Fayard et La Documentation Française, 2013.

Baulant, Camille. "The Role of Networks for Helping Firms and Countries Invent New Competitive Strategies Well Adapted to the World Knowledge Economy." Journal of Economics Issues 49, 2, (2015): 563-573.

Baumard, Philippe, Harbulot, Christian. "Perspectives historiques de l'intelligence économique." Revue d'intelligence économique, Vol. 1, No. 1, Mars (1997): 50-65.

Ben-Sahar, Tal. Happier: Learn the secret to daily joy and lasting fulfilment. New-York, USA: Mc GrawHill, 2007.

Bloch, Alain. L'Intelligence économique. Paris, France: Economica, collection Economie Poche, $\mathrm{n}^{\circ} 38$, 2ième édition, 1999.

Boyer, Robert et Jacques Mistral. Accumulation inflation et crises. Paris, France: P.U.F., collection économie en liberté, 1978.

Brown, John S \& Paul Duguid. "Organizational learning and communities-of practice: towards a unified view of working, learning and innovation." Organization Science 2 (1991): 40-57.

Clark, Andrew, Sarah Flèche and Claudia Senik. "Economic Growth Evens-Out Happiness: Evidence from Six Surveys." Review of Income and Wealth Vol. 62, (2016): 405-419.

Cohen, Daniel. Homo Economicus, prophète (égaré) des temps nouveaux. Paris, France: Albin Michel, 2013.

Collins, Jim. "Level 5 Leadership: the Triumph of Humility." On leadership, HBR's 10 Must Reads, Boston, Massachusetts: Harvard Business Review Press, [2001] 2011: 115-136.

D'Aveni, Richard. Strategic Capitalism: The New Economic Strategy for Winning the Capitalist Cold War. New-York, USA: McGraw-Hill Contemporary Edition, 2012.

De Vinci, Leonard. Les carnets de Léonard de Vinci, traduction françaises 1942. Paris, France: Gallimard, collection TEL, 2 vol., [1519] 1987.

Dolan, Paul. Happiness by Design, change what you do, not how to think. New-York, USA: Hudson Street Press, 2014.

Delmas-Marty, Mireille. Aux quatre coins du monde, petit guide de navigation sur l'océan de la mondialisation. Paris, France: Le Seuil, 2016.

Drucker, Peter F. "What Makes An Effective Executive." On leadership, HBR's 10 Must Reads, Boston, Massachusetts: Harvard Business Review Press, [2001] 2011: 23-36.

Eeasterlin, Richard. "Does Economic Growth improves the Human Lot?" Nations and Household in Economic Growth, essays in honor Moses Abramovitz, by Paul A. David and W. Melvin, New-York, USA: Academic Press, Reader, 1974.

Foray, Dominique and Bengt-Åke Lundvall. "The knowledge-based economy: from economics of knowledge to learning economy." in Foray \& Lundvall (Eds) Employment and Growth in the Knowledge Economy, Paris, France: OECD, 1996. 
Garvin, David A. and Michael A. Roberto. "What you don't know about making decision." On making smart decision, HBR's 10 Must Read, Boston, Massachusetts: Harvard Business Review Press, [2001] 2013: 75-94.

Goleman, Daniel. Attentifs, concentré et libre. Paris, France: Robert Laffont, collection Pocket [2013] 2014.

Goleman, Daniel. "What Makes a Leader?" On leadership, HBR's 10 Must Reads, Boston, MA, Harvard Business Review Press [1996] 2011: 1-22.

Goffee, Robert and Gareth, Jones. "Why Should Anyone Be Led by You?" On leadership, HBR's 10 Must Reads, Boston, MA, Harvard Business Review Press [2000] 2011: 79-96.

Harbulot, Christian. Techniques offensives et guerre économique. Paris, France: La Bourdonnaye, 2014.

Helliwell, John F., Richard Layard and Jeffrey Sachs. World Happiness Report 2016. vol 1, Update, 2016 ,

http://worldhappiness.report/wp-content/uploads/sites/2/2016/03/HR-V1_web.pdf.

Helpman, Elhanan \& Paul Krugman. Market structure and foreign trade. Cambridge, MA: MIT Press, 1985.

Hume, David. Dissertation sur les passions : traité sur la nature humaine. livre II, Paris, France: Flammarion [1759], 1991.

Inglehart, Ronald \& Wayne E. Baker. "Modernization, Cultural Change And the Persistence Of Traditional Values." American Sociological Review. Vol 65, No.1, February, 2000: 19-51.

James, William. Principles of Psychology. New-York, USA: Henry Holt and Co, 1890,

https://archive.org/stream/theprinciplesofp01jameuoft/theprinciplesofp01jameuoft_djvu.txt.

Jakobiak, François. L'Intelligence Economique, la comprendre, l'implanter, l'utiliser. Paris, France: Editions d'Organisation, 2004.

Kahneman, Daniel and Angus Deaton. "High income improves evaluation of life but not emotional wellbeing." PNAS Early Edition, (2010): 1-5.

Kahneman, Daniel. Thinking, fast and slow. United-Kingdom: Penguin Books, 2011.

Koestler, Arthur. Génie et folie des l'homme, le cheval dans la locomotive (le paradoxe humain). Paris, France: Calman Levy, 1988.

Kotter, John P. "What Leaders Really Do." On leadership, HBR's 10 Must Reads, Boston, Massachusetts: Harvard Business Review Press, [2001] 2011: 37-56.

Klasen, Stephan. "Measuring and Monitoring Inclusive Growth: Multiple Definitions, Open Questions, and Some Constructive Proposals." Asia Development Bank, No. 12, June 2010,

https://www.adb.org/sites/default/files/publication/28492/adb-wp12-measuring-inclusive-growth.pdf.

Kühn, Thomas S. La structure de la révolution scientifique. Paris, France: Flammarion, nouvelle édition, 1970.

Langer, Ellen J. Mindfulness. Reading, MA: Addison Wesley. 1989.

Le Moigne, Jean-Louis. La modélisation des systèmes complexes. Paris, France: Dunod. [1990] 1995.

Levet, Jean-Louis. Intelligence Economique, mode de pensée, mode d'action. Paris, France: Economica, collection l'IE, 2001.

Massé, Guy and Françoise Thibaut. Intelligence économique : Guide pour une économie de l'intelligence. Paris, France : Editions De Boeck Université, 2000.

Mill, John Stuart. "Thoughts on poetry and its varieties." in J. M. Robson \& J. Stillinger (Eds.), Collected Works of John Stuart Mill, Vol. 1. Autobiographical and Literary Essays. Toronto, Canada: University of Toronto Press. [1833] (1981): 343-365.

Morin, Edgar. La méthode : la nature de la nature. Paris, France: Le Seuil [1977] $2^{\text {nd }}$ édition, tome 1, 1981.

Morin, Edgar. La voie, pour l'avenir de l'humanité. Paris, France: Fayard, 2011.

Muldoon, Ryan. "Diversity and the Division of Cognitive Labor." Philosophy Compass, 8/2 (2013): 117125.

Nelson, Richard R. and Sidney .G Winter. An Evolutionary Theory of Economic Change. Boston, MA: Harvard University Press, 1982.

Piaget, Jean. Le Comportement, moteur de l'Evolution. Paris, France: Gallimard, Collection Idées, 1976.

Polanyi, Karl. La Grande Transformation: aux origines politiques et économiques de notre temps. Bibliothèque des sciences humaines. Paris, France: Gallimard, [1944] 1983.

Porter, Mickael E. "Competitive Advantage of Nations." Harvard Business Review, March-April issue: 73-91, 1990.

Porter, Michael E. and Mark R. Kramer. „Creating Shared Value.” Harvard Business Review, January 2011 Issue. https://hbr.org/2011/01/the-big-idea-creating-shared-value. 
Porter, Michael E. Social Progress Indexes Data Base, November 2016, http://www.socialprogressimperative.org/countries/usa/.

Kotter, John P. "Leading Change: Why Transformation Effort Fails." Harvard Business Review (January 2007):96-103.

Polanyi, Karl. The Great Transformation. Traduction française : La Grande Transformation : aux origines politiques et économiques de notre temps. Paris, France: Gallimard, Bibliothèque des sciences humaines [1944] 1983.

Rauniyar, Ganesh and Ravi Kanbur. "Inclusive Development: Two Papers on Conceptualization, Application, and the ADB Perspective." World Affairs Cornell University, 2010,

http://www.kanbur.dyson.cornell.edu/papers/ADBCompendiumInclusiveDevelopment.pdf.

Rostow; Walt W. The Stages of Economic Growth: A non-communist manifesto, MA, USA: Cambridge University Press, 1960,

https://www.ou.edu/uschina/gries/articles/IntPol/Rostow.1960.Ch2.pdf.

Sen, Amartya. Commodities and Capabilities. Oxford, UK: Oxford University Press, India Paper Back, 1999.

Shapiro, Carl and Joseph E. Stiglitz. Equilibrium Unemployment as Worker Disciplines Devices. The American Economic Review, vol 74, 3, 1984, pp 433-444.

Stiglitz, Joseph E., Amartya Sen \& Jean-Paul Fitoussi. Commission sur la mesure des performances économiques et du progrès social. Paris, Juillet, 25, 2008.

Thaler, Richard H. \& Cass R. Sunstein. Nudge, la méthode douce pour inspirer la bonne décision. Paris, France: Vuibert, collection Pocket [2008] 2010.

Seligman, Martin E. P. Learned Optimism: How to Change Your Mind and Your Life. New York, USA: Knopf. Reprint edition, Penguin Books, reissue edition, Free Press [1991] 1998.

Simon, Hebert A. "A Behavioral Model of Rational Choice." Quaterly Journal of Economics, 69, 1955:99-118.

Smith, Adam. Théorie des sentiments moraux. Paris, France: PUF, [1750], 1991.

Smith, Adam. Recherches sur la nature et les causes de la richesse des nations. Paris, France: Flammarion [1776], 1991.

Valéry, Paul. CEuvres complètes. (2 t) et Cahiers. (2 t.), Paris, France: NRF, Collection La Pléiade [18941914] 1989.

Veblen, Thorstein. "Why is Economics Not an Evolutionary Sciences?" Quarterly Journal of Economic 12, 2 (1898): 373-397.

Watzlawick, Paul, Janet H? Beavin and Don D. Jackson. Une logique de la communication. Paris, France: Seuil, 1972.

Wilensky, Henry. Organizational intelligence: Knowledge and policy in Government and industry. NewYork, USA: Basic Book, 1967. 